\title{
Penciptaan Film Animasi 2D Diadaptasi Dari Puisi "Engkau"
}

\author{
Muhamad Hadi Hibatullah ${ }^{1}$, Tanto Harthoko ${ }^{2}$, Agnes Karina Pritha Atmani ${ }^{3}$ \\ Program Studi Animasi, Fakultas Seni Media Rekam, \\ Institut Seni Indonesia Yogyakarta \\ e-mail: muhamadhadihibatullah@gmail.com ${ }^{1}$, \\ tantoh@isi.ac.id ${ }^{2}$, kagnes@isi.ac.id ${ }^{3}$
}

\begin{abstract}
Abstrak
Karya sastra yang diadaptasi ke film sudah tidak asing lagi bagi masyarakat umumnya. Menyikapi masalah tersebut, film animasi "Engkau" dibuat dengan maksud untuk mempermudah seorang penyair menyampaikan pesan dari puisinya dalam bentuk audiovisual kepada pembaca secara menarik dan unik melalui film animasi yang merupakan salah satu media yang populer sebagai media penyampaian. Film animasi "Engkau" merupakan film yang diadaptasi dari puisi yang berjudul sama "Engkau" dalam kumpulan puisi "Aku Ingin Mencumbu Waktu" dengan teknik animasi 2D.

Puisi yang berjudul "Engkau" dari kumpulan puisi "Aku Ingin Mencumbu Waktu" menceritakan sebuah perasaan seseorang yang mengagumi dan mencintai seseorang secara mendalam, tidak memperdulikan waktu dapat mencegah dan menghambatnya untuk tetap mencintai. Puisi "Engkau" dalam setiap baitnya nanti akan adaptasi menjadi sebuah film animasi 2D, menjadikan animasi ini berbeda dengan yang lain.
\end{abstract}

Kata kunci: puisi, adaptasi karya sastra, animasi puisi, puisi "engkau"

\begin{abstract}
Literary works adapted to the film are familiar to the general public. In response to the problem, the animated film "Engkau" is made with the intention to make it easier for a poet to deliver the message of his poems in audiovisual form to the reader in an interesting and unique way through the animated film which is one of the popular media as a medium of delivery. The animated film "Engkau "is a film adapted from a poem entitled "Engkau" in a collection of poems "Aku Ingin Mencumbu Waktu" with 2D animation techniques.

The poem entitled "Engkau "from the collection of poems "Aku Ingin Mencumbu Waktu " tells a feeling of someone who admires and loves someone deeply, no matter how long it can prevent and keep him from loving. The poem "Engkau" in each verse will later be adapted into a $2 D$ animated film, making this animation different from the others.
\end{abstract}

Keywords: poetry, adaptation of literary works, poetry animation, poem "engkau" 